working of this Station was inspected by many prominent people, among them being Lord Tennyson and Lord Kelvin.

The first two paid wireless messages ever dispatched were sent by Lord Kelvin, one to Sir William Preece at the General Post Office on June 3, 1898, and the other to Sir George Stokes, the Cambridge physicist. Lord Kelvin insisted on paying for the messages as an indication of his belief in the possibilities of wireless communication at a time when there was much scepticism. A photograph of the memorial to Marconi on the cliffs of Alum Bay appears in The Times of April 11. Four bronze plaques are attached to the memorial; one pays tribute to "Marconi and his collaborators, who carried out from Dec. 6, 1897, to May 26, 1900 , a series of experiments which constituted some of the most important phases of their early pioneer work in the development of wireless communication of all kinds". Another records the production of the Transatlantic Times in 1899, the first newspaper to be produced at sea, which received information by wireless telegraphy from the Needles Station and printed it in the United States liner St. Paul.

\section{Croydon Natural History and Scientific Society}

Is was on April 6, 1870, that the Croydon Microscopic Club, the forerunner of the Croydon Natural History and Scientific Society, held its inaugural meeting, so the Society is practically a contemporary of NATURE. According to the early records, about a hundred and fifty were present at the meeting, "not all of the savantissime school, it is true-but the majority evincing an earnest desire for the pursuit of science in one of its most interesting branches". Microscopical demonstrations were arranged. The chair was taken by Mr. H. Lee, who reported that the Club included three fellows of the Royal Society, four of the Linnean Society, three of the Geological Society (one of whom was treasurer of the Club), and several members of the Royal Microscopical Society and the Quekett Microscopical Club. Among the speakers were Frank Buckland and Dr. J. S. Bowerbank, F.R.S.

Further meetings were held during 1870. On May 4, J. W. Flower read a paper on the microscopical organisms of the flints. On May 14, the Club formed a party with members of the Quekett to explore the River Wandle for freshwater organisms. The quest was apparently not very successful, but mention is made of the fact that the party managed to obtain adequate refreshment of bacon and eggs, cold beef, tea, etc., at the "Greyhound". On May 28, the Club visited the house and grounds, at Park Hill, of Mr. Flower, who "had provided 2 cart loads of Flints for them to crack" in search of fossil foraminifera, etc.; "the popping of champagne corks was frequently heard above the sound of the geological hammers". On July 30, Mr. H. W. Peek, M.P., entertained the Club, and on November 30, the Club's first soirée, with exhibits, was held in the Public Hall, Croydon. Lest it be thought that undue prominence was given to refreshment of the body rather than the mind, we hasten to add that the Croydon Natural History and Scientific Society, the honorary secretary of which is Capt. B. V. Pring, 33 The Windings, Sanderstead, Surrey, has a distinguished scientific record and normally holds regular meetings twice a month at the Central Library, Croydon.

\section{Bacteriological Warfare}

IN his inaugural thesis (Thèse de Paris 1940, No. 19) on the experimental production of epidemics and epizootics, Dr. Ernest Sarfati states that the question of bacteriological warfare formed the subject of an inquiry in 1923 by a committee of experts including Profs. Bordet of Brussels, Cannon of Harvard, Madsen of Copenhagen, and Pfeiffer of Leipzig. As the result of the inquiry a protocol was issued at Geneva on June 17, 1925, signed by representatives of Germany, the United States, Great Britain, France, Italy, and about forty other nations who undertook that their countries would not take part in bacteriological warfare, the possibility and dangers of which they fully recognized. The experts classified the mode of transmission of bacteria into an enemy country as follows: (1) transportation by aircraft or spies ; (2) dispersal of microbic cultures in liquid or solid form ; (3) transmission by intermediate hosts such as rats or lice, or the poisoning of projectiles or steel weapons.

The epidemics which theoretically might be produced artificially by these means include malaria, yelıow fever, bacillary dysentery, diphtheria, typhus, plague, cholera, enteric fever, Malta fever, tuberculosis, smallpox, influenza, rabies, poliomyelitis and epidemic encephalitis, while the principal epizootics would be glanders, anthrax, foot-and-mouth disease, peri-pneumonia of eattle, and pernicious anæmia of horses. Special circumstances, however, are required to produce epidemies and epizootics, and attempts have repeatedly been made to destroy certain animal species, particularly locusts, without success. Dr. Sarfati comes to the conclusion that while bacteriological warfare is not impossible, it would only succeed in strictly localized areas, in which case the ordinary methods of prophylaxis, including the use of serums and vaccines, would prevent the spread of infection.

\section{Sir Leonard Woolley and Indian Archæological Studies}

As anticipated, the reception accorded by Indian opinion to Sir Leonard Woolley's report on the Archæological Department and the state of archæological research in Indis can only be described as mixed. To a great extent, eriticism of its findings has been inspired by umbrage taken that his expert advice should have been invited by the authorities and his verdict received and published, without sufficient regard being paid to the views and opinions of those among the Indians themselves considered competent to judge. Thus it may be considered that it was to some extent a reaction against any attempt on the part of the Government to restrict existing archæological activities in the field that was responsible for the resolution of the Archaic and 